\title{
EARLY BOMB RADIOCARBON DETECTED IN PALAU ARCHIPELAGO CORALS
}

\author{
Danielle Glynn ${ }^{1,2} \bullet$ Ellen Druffel $^{1} \bullet$ Sheila Griffin $^{1} \bullet$ Robert Dunbar $^{3} \bullet$ Michael Osborne $^{3} \bullet$ \\ Joan Albert Sanchez-Cabeza ${ }^{4}$
}

\begin{abstract}
In order to evaluate the variability in surface water masses in the Western Pacific Warm Pool, we report highprecision radiocarbon measurements in annual and seasonal bands from Porites lutea corals collected from the Palau Archipelago $\left(7^{\circ} \mathrm{N}, 134^{\circ} \mathrm{E}\right)$. Annual coral bands from 1945 to 2008 and seasonal samples from 1953 to 1957 were analyzed to capture the initial early input of bomb ${ }^{14} \mathrm{C}$ from surface thermonuclear weapons testing in the Marshall Islands. Results show a pre-bomb average $\Delta^{14} \mathrm{C}$ value of $-54.9 \%$ between 1945 and early 1953 . Beginning early in 1954, there is a rapid increase to a maximum of $-23.1 \%$ at the start of 1955 . Values continued to rise after 1957 to a post-bomb peak of $141 \%$ by 1976 . The large initial rise in $\Delta^{14} \mathrm{C}$ cannot be accounted for by air-sea $\mathrm{CO}_{2}$ exchange. Results therefore suggest that the primary cause of this increase is the lateral advection of fallout-contaminated water from the Marshall Islands to Palau via the North Equatorial Current and then to the North Equatorial Countercurrent.
\end{abstract}

\section{INTRODUCTION}

Atmospheric ${ }^{14} \mathrm{CO}_{2}$ exchanges with $\mathrm{CO}_{2}$ in the ocean to become part of the pool of dissolved inorganic carbon (DIC) in seawater. It takes approximately $10 \mathrm{yr}$ for atmospheric ${ }^{14} \mathrm{CO}_{2}$ to exchange with the surface ocean through air-sea gas exchange. The $\Delta^{14} \mathrm{C}$ values then decrease with depth in the ocean due to decay and isolation from the atmospheric source of ${ }^{14} \mathrm{C}$. Hermatypic, or reef-building, corals that grow in the surface ocean incorporate DIC into their aragonitic skeletons and record the $\Delta^{14} \mathrm{C}$ value of the surrounding seawater at the time of formation. Annual density bands, which are discernable when a coral slab is X-rayed, can be dated and used as proxies of past changes in water mass (Druffel and Linick 1978) and climate (Guilderson and Schrag 1998).

Human-induced atmospheric injection of ${ }^{14} \mathrm{C}$ by thermonuclear bomb testing occurred during the 1950s and early 1960s (Yang et al. 2000). Global, regional, and local nuclear fallout sources have been observed in coral records. Ground-based nuclear explosions at Bikini Atoll $\left(11^{\circ} 35^{\prime} \mathrm{N}\right.$, $165^{\circ} 23^{\prime} \mathrm{E}$ ) turned coral, seawater, and other materials at the detonation site into reactive dust particles containing higher $\Delta^{14} \mathrm{C}$ values, known as "close-in fallout." The surface nuclear explosion on 1 March 1954 at Bikini Atoll liberated and contaminated particles that eventually condensed into droplets that fell out of the atmosphere (Glasstone and Dolan 1977). Fallon and Guilderson (2008) observed a rapid rise of $\Delta^{14} \mathrm{C}$ values in an Indonesian coral approximately 11 months after this nuclear detonation, suggesting that nuclear close-in fallout led to a more rapid absorption of ${ }^{14} \mathrm{C}$ into the water and coral than air-sea gas exchange alone. However, the processes by which this fallout was incorporated back into the environment are not well known.

The Palau Archipelago lies in a complicated region of oceanic currents between the Philippine Sea and the Pacific. Tradewinds drive surface currents from east to west in the tropical Pacific, forming the North Equatorial Current (NEC). In the western Pacific, these waters then turn into the eastwardflowing North Equatorial Countercurrent (NECC), which brings water to Palau. The strength and position of both currents has been found to vary seasonally and show large interannual variability

\footnotetext{
${ }^{1}$ Earth System Science Department, University of California, Irvine, Irvine, California 92697-3100, USA.

${ }^{2}$ Corresponding author. Email: dglynn@uci.edu.

${ }^{3}$ Department of Environmental Earth System Science, Stanford University, Stanford, California 94305-2115, USA.

${ }^{4}$ Instituto de Ciencias del Mar y Limnologia, Universidad Nacional Autónoma de México, 04510 Ciudad de México, México.
}

(c) 2013 by the Arizona Board of Regents on behalf of the University of Arizona

Proceedings of the 21st International Radiocarbon Conference edited by A J T Jull \& C Hatté

RADIOCARBON, Vol 55, Nr 2-3, 2013, p 1659-1664 


\section{Glynn et al.}

with greatly altered regional circulation occurring during El Niño Southern Oscillation (ENSO) events (Osborne et al., forthcoming).

A coral record of $\Delta^{14} \mathrm{C}$ from the western tropical Pacific is presented herein. High-precision $\Delta^{14} \mathrm{C}$ measurements show an increase in $\Delta^{14} \mathrm{C}$ values during 1954, indicating the presence of seawater contaminated by nuclear weapons detonations in the Marshall Islands.

\section{METHODS}

Palau Archipelago $\left(7^{\circ} 17^{\prime} \mathrm{N}, 134^{\circ} 15^{\prime} \mathrm{E}\right)$ is located in the western tropical Pacific Ocean. This archipelago is east of the Philippines Islands and north of Indonesia. The site is $\sim 3400 \mathrm{~km}$ west of Bikini Atoll, where the largest US thermonuclear weapons test occurred on 1 March 1954 with a bomb detonation yield of 15 MT (Yang et al. 2000).

Coral cores of Porites lutea were hydraulically drilled with a diamond-tipped 7.5-cm-diameter corer in November 2008 from Ulang Channel, Koror Island, Palau. Cores UC-1 and UC-2 were collected from a coral that died during the 1998 bleaching event (Osborne et al., forthcoming). In order to extend the record to 2008 and overlap these cores for precise cross-dating, cores UC-3 and UC-4 were collected from a small living Porites colony immediately adjacent to the large dead coral. All coral heads were at a depth of $\sim 13 \mathrm{~m}$ and showed relatively little bioerosion (Osborne et al., forthcoming).

The cores were cut into slabs, cleaned, $\mathrm{X}$-rayed, and mapped using $\delta^{18} \mathrm{O}$ values (Osborne et al., forthcoming). The $\delta^{18} \mathrm{O}$ results were used for assignment of annual bands because cooler and higher salinity waters cause corals to produce aragonite with higher $\delta^{18} \mathrm{O}$ values. This method provides better dating accuracy than the use of density banding alone and has an approximate uncertainty of \pm 3 months (M Osborne, personal communication).

After $\delta^{18} \mathrm{O}$ analyses were performed, the coral slabs were sampled using a hand-held Dremel ${ }^{\circledR}$ tool with a diamond-tipped drill-bit. Annual samples were collected from slabs UC-2-3 (1945-1982) and UC-3-2 (1982-2008) with annual growth varying from 1 to $1.5 \mathrm{~cm}$. Seasonal samples were taken for the years 1953-1957 from slab UC-2-3. Seasonal samples were drilled every $1 \mathrm{~mm}$.

Samples $(\sim 8 \mathrm{mg})$ were acidified with $85 \%$ phosphoric acid to hydrolyze the aragonitic $\left(\mathrm{CaCO}_{3}\right)$ skeleton to $\mathrm{CO}_{2}$ gas. The resultant $\mathrm{CO}_{2}$ was reduced on iron powder with hydrogen gas to produce graphite (Vogel et al. 1987). The graphite was analyzed for ${ }^{14} \mathrm{C}$ at the Keck Carbon Cycle AMS laboratory using standard techniques (Santos et al. 2007). ${ }^{14} \mathrm{C}$ results are reported as $\Delta$ values that have been corrected for known age to 1950 according to convention (Stuiver and Polach 1977). There is a $\pm 2 \%$ total uncertainty in our results, as determined by multiple analyses of a modern coral standard and duplicate coral analyses (Druffel et al. 2007).

\section{RESULTS AND INTERPRETATION}

\section{Annual Results}

As shown in Figure 1, during the period 1945 to 1953 , Palau coral $\Delta{ }^{14} \mathrm{C}$ values ranged from $-57.9 \%$ to $-51.8 \%$ with a pre-bomb average of $-54.9 \%(n=9)$. The 1955 band showed a rapid increase of $\Delta^{14} \mathrm{C}$ to $-23.1 \%$. There was a decrease to $-43.7 \%$ by 1957 . A maximum post-bomb value of $141 \%$ was reached in 1976. After a few years of very intensive nuclear testing, the Limited Test Ban Treaty went into effect in 1963 and surface ocean values have decreased, due to mixing with subsurface waters. 


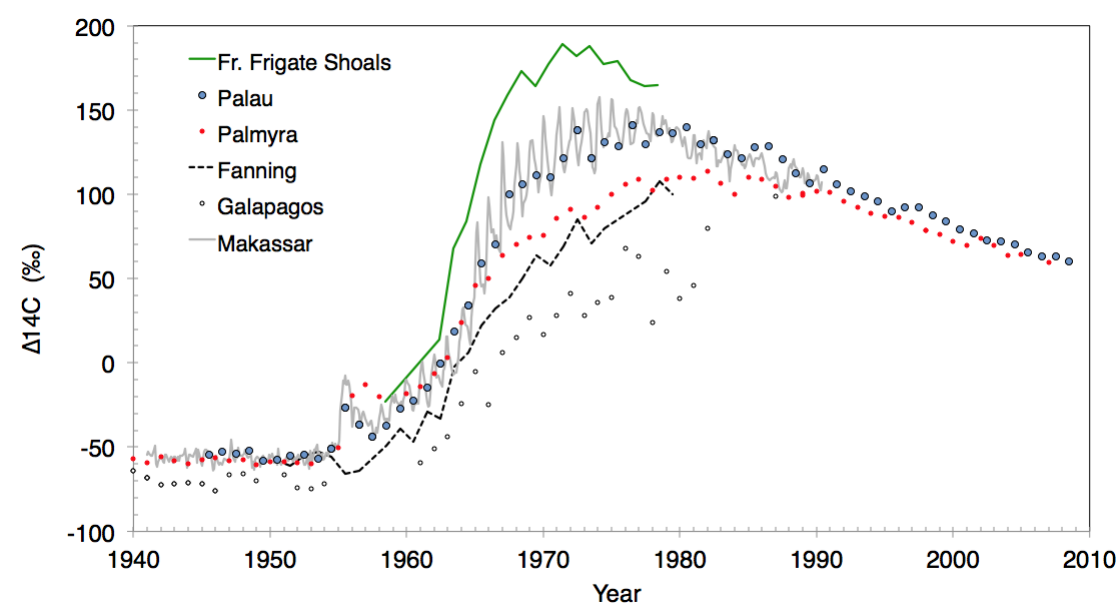

Figure $1 \Delta^{14} \mathrm{C}$ records for corals from Palau (this study), French Frigate Shoals $\left(24^{\circ} \mathrm{N}, 166^{\circ} \mathrm{W}\right)$, Fanning Island $\left(4^{\circ} \mathrm{N}, 159^{\circ} \mathrm{W}\right)$, Galapagos Islands $\left(1^{\circ} \mathrm{S}, 90^{\circ} \mathrm{W}\right)$ (Druffel 1987$)$, Palmyra Atoll $\left(6^{\circ} \mathrm{N}\right.$, $162^{\circ} \mathrm{W}$ ) (Druffel-Rodriguez et al. 2012), and Makassar Straits $\left(5^{\circ} \mathrm{S}, 119^{\circ} \mathrm{E}\right.$ ) (Fallon and Guilderson 2008). Tic marks indicate 1 January.

Also included in Figure 1 are other time series from corals in the Pacific Ocean to put our data into perspective. The data from Palau and Makassar corals record the initial bomb spike contamination at roughly the same time, reaching an early maximum by mid-1954. Both locations are west of the Marshall Island nuclear detonations, being both downwind and downstream of the NEC. A $\Delta^{14} \mathrm{C}$ record from a third site, Palmyra Atoll, located $7000 \mathrm{~km}$ east of Palau, shows the presence of early bomb ${ }^{14} \mathrm{C}$ at the beginning of 1956, delayed by $1 \mathrm{yr}$ from that at Palau and Makassar. This delay is likely due to the additional time required for bomb-contaminated waters to flow from the NEC to the mid-Pacific via the NECC (Druffel-Rodriguez et al. 2012). A fourth site, Fanning Island, $400 \mathrm{~km}$ southeast of Palmyra, shows no early bomb ${ }^{14} \mathrm{C}$ peak (Figure 1) because the Fanning coral is influenced by the westward South Equatorial Current that originates from the eastern tropical Pacific.

The French Frigate Shoals are located northwest of Hawaii in the subtropical gyre and outside of the currents that affect Palau. This location reaches a higher maximum $\Delta^{14} \mathrm{C}$ value in the $1970 \mathrm{~s}(188 \%$ o) due to the lack of upwelling in the gyre, allowing for buildup of high values through air-sea gas exchange (Druffel 1987). This mid-gyre location was too far from Bikini Atoll to be influenced by the early input of bomb ${ }^{14} \mathrm{C}$. The Galapagos coral is located in the east equatorial Pacific region that is strongly dominated by coastal upwelling from the Peru Current as well as equatorial divergence; these influences likely masked any initial peak. All of the time series exhibit the same trend of increasing levels of bomb ${ }^{14} \mathrm{C}$ until peaking in the 1970s and 1980s.

\section{Seasonal Results}

As determined from seasonal $\Delta^{14} \mathrm{C}$ measurements (Figure 2), the pre-bomb average value in 1953 was $-56.5 \%$ o $(n=17)$, which is not significantly different from the mean annual average for $1945-$ 1953 (-54.9\%). The first thermonuclear bomb test was on 1 March 1954 (i.e. 1954.16), and is first noticed by late May (i.e. 1954.40) (Figure 2). Shortly after this, $\Delta^{14} \mathrm{C}$ values increased to a maximum of $-23.1 \%$ by the start of 1955 ; thereafter values declined monotonically. The annual averages of seasonal measurements and the annual measurements agree for all years, except 1954 when $\Delta^{14} \mathrm{C}$ values changed dramatically (Figure 2). 


\section{Glynn et al.}

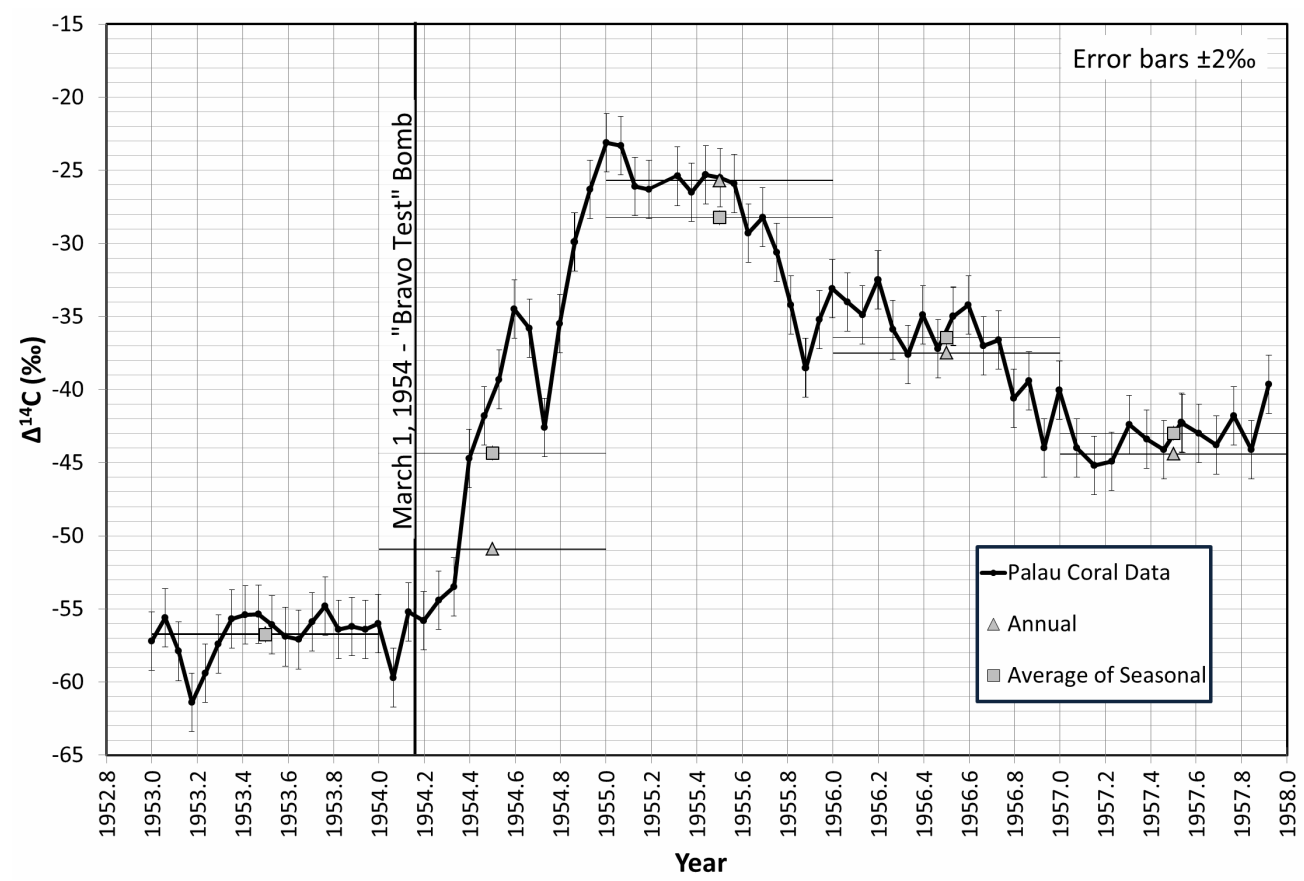

Figure 2 Seasonal $\Delta^{14} \mathrm{C}$ results from 1953 to 1958 in the Palau coral showing the input of early bomb ${ }^{14} \mathrm{C}$. The "Annual" data are the $\Delta^{14} \mathrm{C}$ values for annual bands measured separately. Those marked "Average of Seasonal" are the average of the $\Delta^{14} \mathrm{C}$ values for all seasonal measurements within a given year.

During the period of thermonuclear bomb testing, the gradient between air and sea $\Delta^{14} \mathrm{C}$ values was exceptionally high because bombs continuously produced ${ }^{14} \mathrm{C}$ in the atmosphere. Maximum atmospheric $\Delta^{14} \mathrm{C}$ values of $900-1000 \%$ were reached in the Northern Hemisphere by 1964 (Nydal and Lövseth 1985). The air-sea gradient caused an increase in net absorption of ${ }^{14} \mathrm{C}$ by the oceans. Because it takes $\sim 10 \mathrm{yr}$ for the ${ }^{14} \mathrm{C}$ to become well-mixed with the upper ocean due to air-sea gas exchange, this mechanism cannot explain the very rapid increase we observe in the Palau coral in the early 1950s. Our data suggest that ${ }^{14} \mathrm{C}$ fallout had a transit time of $\sim 3$ months (black arrow, Figure 2) to reach our site and become incorporated into the coral; this is much faster than air-sea gas exchange could provide. Thus, nuclear fallout caused by the Marshall Island testing in 1954 was likely carried by the NECC and caused the rapid rise of $\Delta^{14} \mathrm{C}$ values recorded in our Palau coral.

\section{CLIMATIC INFLUENCES ON THE $\Delta^{14} \mathrm{C}$ RECORD}

In the tropical Pacific, interannual $\Delta^{14} \mathrm{C}$ variability is dominated by the state of the coupled ocean/ atmosphere phenomenon known as El Niño Southern Oscillation (ENSO). The $\Delta^{14} \mathrm{C}$ values in the South Equatorial Current (SEC) are low during normal and La Niña periods, because this current is diluted by low $\Delta^{14} \mathrm{C}$ waters that upwell in the equatorial Pacific (Guilderson and Schrag 1998). During El Niño events, the normal easterly tradewinds cease or reverse causing the ocean thermocline to level out and prevent the upwelling of subsurface waters, resulting in the accumulation of higher $\Delta \Delta^{14} \mathrm{C}$ waters in the surface of the tropical mid- and east Pacific.

Warmer sea surface temperature (SST) anomalies in the central and eastern tropical Pacific correspond to El Niño conditions; however, the western Pacific is cooler than normal during this climatic event. Osborne et al. (forthcoming) found higher $\delta^{18} \mathrm{O}$ during El Niño years in corals from Palau, 
indicative of high salinity, the primary controller of $\delta^{18} \mathrm{O}$ at this site, and also cooler SST. Strong El Niño events as determined by the Oceanic Niño Index (ONI) that occurred during the highlighted years (Figure 3) are defined by having an increased surface temperature anomaly of $\geq 1.5^{\circ} \mathrm{C}$ in the Niño3.4 region $\left(120^{\circ}-170^{\circ} \mathrm{W}\right.$ and $\left.5^{\circ} \mathrm{S}-5^{\circ} \mathrm{N}\right)$ for 3 or more months in the year (NOAA/NWS 2012).

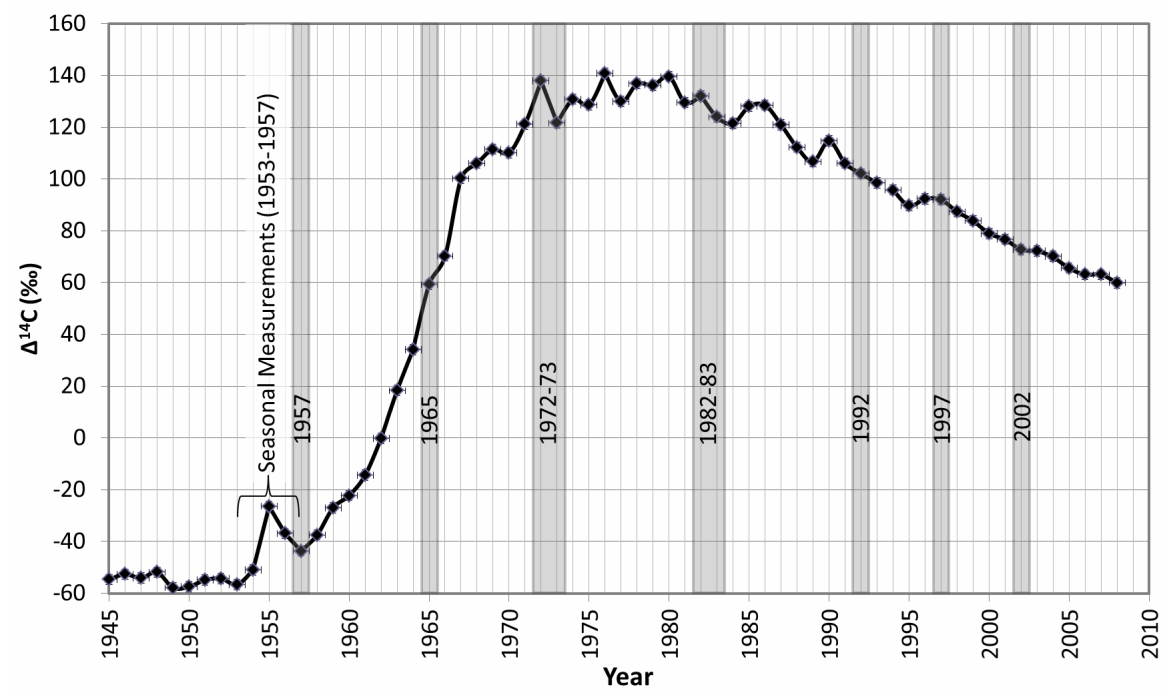

Figure 3 Annual $\Delta^{14} \mathrm{C}$ results from the Palau coral from 1945 to 2008. Years highlighted in gray correspond to strong El Niño years (Oceanic Niño Index, NOAA/NWS 2012). Also indicated is where seasonal samples were taken for a detailed look at the time period when nuclear detonations began (see Figure 2). Tic marks indicate the year's average value, while the horizontal error bars indicate 1 January to 31 December.

El Niño conditions appear to correspond to some of the high $\Delta^{14} \mathrm{C}$ values in our annual results (Figure 3). There is a maxima during the strong El Niño years of 1972/1973, and possibly in 1982/ 1983 and 1997 (Figure 3). La Niña conditions bring stronger currents from the east Pacific whose waters supposedly have lower $\Delta{ }^{14} \mathrm{C}$ values due to upwelling that dilutes the labeled waters from the Marshall Islands. The period of interest, 1954-1955, had moderately strong La Niña conditions, and may have diluted the regional bomb signal that was dominant at that time. However, this is a complicated region with converging surface ocean currents that carry different source waters to influence this signal. There is a complex interaction between seasonally varying local winds and externally forced variability from ENSO events that control ${ }^{14} \mathrm{C}$. Additional coral-based records from this region may provide a better idea of the current mixing in the western Pacific and whether or not there is a concrete connection between ENSO events and $\Delta{ }^{14} \mathrm{C}$ values.

\section{CONCLUSION}

The large increase in Palau coral $\Delta^{14} \mathrm{C}$ values seen $\sim 3$ months after the Bikini Atoll thermonuclear detonation of 1954 suggests that fallout and not air-sea gas exchange was the cause of this rise. Due to the complicated currents influencing this region, it is not possible at this time to determine the effects of ENSO on ${ }^{14} \mathrm{C}$. However, further coral studies should take close-in fallout into account when assigning accurate dates for sites in close proximity to nuclear testing locations. 


\section{Glynn et al.}

\section{ACKNOWLEDGMENTS}

We thank John Southon and the staff of the Keck CCAMS lab for advice and assistance, and Fanny Chahine and the IAEA Coordinated Research Project on Nuclear and Isotopic Studies of the El Niño Phenomenon in the Ocean for support. We acknowledge funding from the NSF Chemical Oceanography and Climate Dynamics Programs.

\section{REFERENCES}

Druffel ERM. 1987. Bomb radiocarbon in the Pacific: annual and seasonal timescale variations. Journal of Marine Research 45(3):667-98.

Druffel ERM, Linick TW. 1978. Radiocarbon in annual coral rings of Florida. Geophysical Research Letters 5(11):913-6.

Druffel ERM, Griffin S, Beaupré SR, Dunbar RB. 2007. Oceanic climate and circulation changes during the past four centuries from radiocarbon in corals. Geophysical Research Letters 34: L09601, doi:10.1029/ 2006GL028681.

Druffel-Rodriguez KC, Vetter D, Griffin S, Druffel ERM, Dunbar RB, Mucciarone DA, Ziolkowski LA, Sanchez-Cabeza J-A. 2012. Radiocarbon and stable isotopes in Palmyra corals during the past century. Geochimica et Cosmochimica Acta 82:154-63.

Fallon SJ, Guilderson TP. 2008. Surface water processes in the Indonesian throughflow as documented by a high-resolution coral $\Delta^{14} \mathrm{C}$ record. Journal of Geophysical Research 113: C09001, doi:10.1029/ 2008JC004722.

Glasstone S, Dolan P. 1977. The Effects of Nuclear Weapons. 3rd edition. US Department of Defense. Chapter IIa. URL: http://www.cddc.vt.edu/host/atomic/nukeffct/index.html.

Guilderson T, Schrag D. 1998. Abrupt shift in subsurface temperatures in the tropical Pacific associated with changes in El Niño. Science 281(5374):240-3.

NOAA/NWS [Internet]. Historical El Niño/La Niña Episodes 1950-present [cited 8 October 2012]. Available from http://www.cpc.ncep.noaa.gov/.

Nydal R, Lövseth K. 1983. Tracing bomb ${ }^{14} \mathrm{C}$ in the atmosphere 1962-1980. Journal of Geophysical Research 88(C6):3621-46.

Osborne M, Dunbar RB, Muccairone D, Sanchez-Cabeza JA, Druffel ERM. Forthcoming. Regionally consistent calibrations of coral proxy records from Palau, West Pacific Warm Pool (WPWP). Paleoceanography.

Santos GM, Moore RB, Southon JR, Griffin S, Hinger E, Zhang D. 2007. AMS ${ }^{14} \mathrm{C}$ sample preparation at the KCCAMS/UCI Facility: status report and performance of small samples. Radiocarbon 49(2):255-69.

Stuiver M, Polach HA. 1977. Discussion: reporting of ${ }^{14} \mathrm{C}$ data. Radiocarbon 19(3):355-63.

Vogel JS, Southon JR, Nelson DE. 1987. Catalyst and binder effects in the use of filamentous graphite for AMS. Nuclear Instruments and Methods in Physics Research B 29(1-2):50-6.

Yang X, North R, Romney C, Richards PG. 2000. Center for Monitoring Research Nuclear Explosion Database (Rev. 3). In: CMR Technical Report No. CMR-00/16. August 2000. Arlington: CMR. 